\title{
Determination of the application of contradictoire delimitatie principles in collecting physical data in the magetan national land agency office (study in magetan district)
}

\author{
Determinação da aplicação dos princípios delimitatie contradictoire na coleta de dados físicos no \\ escritório da agência nacional de terras magetano (estudo no distrito magetano)
}

Determinación de la aplicación de principios de delimitatie contradictoire en la recopilación de datos físicos en la oficina de la agencia nacional de tierras de magetan (estudio en el distrito de magetan)

Received: 05/25/2021 | Reviewed: 05/31/2021 | Accept: 06/02/2021 | Published: 06/03/2021

\author{
Wahyu Dwi Puriani \\ ORCID: https://orcid.org/0000-0001-9313-0215 \\ Universitas Sebelas Maret, Indonesia \\ E-mail: puriani43@gmail.com \\ I Gusti Ayu Ketut Rachmi Handayani \\ ORCID: https://orcid.org/0000-0003-4805-3139 \\ Universitas Sebelas Maret, Indonesia \\ E-mail: ayu_igk@yahoo.com \\ Lego Karjoko \\ ORCID: https://orcid.org/0000-0003-3140-5476 \\ Universitas Sebelas Maret, Indonesia \\ E-mail: legokarjoko@staff.uns.ac.id
}

\begin{abstract}
The determination and stipulation of appropriate limits with the principle of Contradictoire Delimitatie becomes the main keys before implementing the land measurement. Lawsuit could arise which results in re-measurement and even the cancellation of the certificate. This research is normative research type (doctrinal research), statute approach and conceptual approach and focuses to the literature study; the research source data is secondary data. The mechanism for determining and stipulation boundaries in land registration has applied the principle of safety. The law consequence if the determination and stipulation boundaries in land are not accordance with the fact in the field resulting in the absence of legal certainty for the certificate of land rights. Conclusion and suggestion in this research is in determination and determination of land plot boundaries in order to achieve legal certainty must in accordance with PP No. 24 of 1997 and PMNA/KaBPN No.3 (Regulation of the Minister of Agrarian and Spatial Planning/Head of BPN) of 1997. Magetan Regency National Land Agency Office before implementing the measurement activities must be thoroughly in the process of determination of land plot boundary in order to reaches the law certainty, it can be accounted for.
\end{abstract}

Keywords: Land boundary; Boundary determination; Legal certainty.

\begin{abstract}
Resumo
A determinação e estipulação de limites apropriados com o princípio de Contradictoire Delimitatie torna-se a chave principal antes de implementar a medição do terreno. Poderão surgir ações judiciais que resultem em remensuração e até mesmo no cancelamento do certificado. Esta pesquisa é do tipo pesquisa normativa (pesquisa doutrinária), abordagem estatutária e abordagem conceitual e enfoca o estudo da literatura; os dados da fonte de pesquisa são dados secundários. O mecanismo para determinar e estipular limites no registro de terras aplicou o princípio de segurança. A consequência legal se os limites de determinação e estipulação na terra não estiverem de acordo com o fato no campo resultando na falta de segurança jurídica para o certificado de direitos fundiários. A conclusão e sugestão desta pesquisa está na determinação e determinação dos limites do terreno, a fim de alcançar a segurança jurídica, deve estar de acordo com PP no 24 de 1997 e PMNA / KaBPN no 3 (Regulamento do Ministro do Ordenamento do Território / Responsável do BPN) de 1997. Magetan Regency National Land Agency Office antes de implementar as atividades de medição deve estar completamente no processo de determinação do limite do terreno, a fim de atingir a certeza da lei, pode ser contabilizado.
\end{abstract}

Palavras-chave: Limite de terra; Determinação de limite; Certeza legal. 


\begin{abstract}
Resumen
La determinación y estipulación de límites adecuados con el principio de Delimitatie Contradictoire se convierte en las claves principales antes de implementar la medición del terreno. Podría surgir una demanda que resulte en una nueva medición e incluso la cancelación del certificado. Esta investigación es de tipo investigación normativa (investigación doctrinal), enfoque de estatuto y enfoque conceptual y se enfoca al estudio de la literatura; los datos de la fuente de investigación son datos secundarios. El mecanismo para determinar y estipular los límites en el registro de la propiedad ha aplicado el principio de seguridad. La consecuencia de la ley si los límites de la determinación y estipulación en la tierra no están de acuerdo con el hecho en el campo resulta en la ausencia de certeza jurídica para el certificado de derechos de la tierra. La conclusión y sugerencia en esta investigación está en la determinación y determinación de los límites de las parcelas para lograr la seguridad jurídica debe de acuerdo con PP No. 24 de 1997 y PMNA / KaBPN No 3 (Reglamento del Ministerio de Ordenación del Territorio y Agrario / Jefe de BPN) de 1997. La Oficina de la Agencia Nacional de Tierras de Magetan Regency antes de implementar las actividades de medición debe estar a fondo en el proceso de determinación del límite de la parcela de tierra para alcanzar la certeza de la ley, se puede contabilizar.
\end{abstract}

Palabras clave: Límite territorial; Determinación de límites; Seguridad jurídica.

\title{
1. Introduction
}

Land is the very basic necessities of human life, human life with perform above ground activities, on the ground so every human always related with the land and it can be said that almost all the human life activities both direct and indirectly must needed land. Land has a function in the framework of state integrity and function as the authorized capital in order to realize the greatest prosperity of the citizen. It means that land for human life and for a state proofed with the stipulated in constitutional in Constitutions 1945 Article 33 Paragraph (3) that: "Earth, water, and space, and the natural riches contained therein, shall be controlled by the state and used for the greatest welfare of the people."

The importance of the land positions for the Republic of Indonesia can be seem in the regulation Article 1 Constitutions Number 5 of 1960 concerning the UUPA (Basic Agrarian Law) which stated:

1. The entire area of Indonesia is the unity of the homeland of entire the Indonesian people, who are united as the Indonesian nation.

2. Entire Earth, water and space including the natural riches contained therein Republic of Indonesia as a gift from God Almighty are the earth, water and space of the Indonesian nation and constitute a national wealth.

3. Related between Indonesian nation and earth, water and space including in the paragraph (2) Article is an eternal relationship.

4. In the meaning of earth, except the earth surface, including the body of the earth underneath as well as those that are under water.

5. In the meaning of water including both inland waters and sea territories of Indonesia.

6. Define with space is the space above the earth and water as referred to in paragraphs (4) and (5) of this article.

One of the purposes of UUPA created is lay the foundations in giving the legal certainty related land ownership rights and the legal certainty so needed to implemented the land registration activity. The purpose implementing the land registration by government to giving the guarantee of land ownership rights, so the land ownership right must registered the land that it is clear who the real owner of the land is.

The result from the process of land registration to the land ownership rights which registered given the Certificate of proof of rights called a certificate. Certificate is the letter of proof of rights as referred to in Article 19 Paragraph (2) point $\mathrm{c}$ UUPA for the land ownership right, the management rights, waqf land, ownership rights to apartment units and mortgage rights, each of which has been recorded in the book of the land concerned (Article 1 point 20 PP No. 24 of 1997 concerning land registration). 
The certificate of land ownership right is given if the conditions specified are met, and one of it is the land ownership obligations to put up a mark on the upper boundary of the land plot and maintain the boundary mark as defined in the Article 17 Government Regulation No. 24 of 1997 which reads:

1. To obtained the physical data which needed for land registration, the land plot to be mapped are measured, after the location has been determined, the boundaries and according to the need, boundary marks are placed in every corner of the land parcel concerned.

2. In the determination of land plot boundary to the systematically land registration and the sporadic land registration are strived for demarcation based on the agreement of interested parties (Principle of Contradictoire Delimitatie).

3. The Placement of boundary signs, including their maintenance, is mandatory implemented by the holder of the land rights concerned.

4. The shape, size and technicality of placing boundary marks shall be determined by the Minister.

The application of Principle of Contradictoire Delimitatie is very important and absolute conditions or conditions that must be met by the land owner before carrying out the process of determining and stipulating the boundaries of land plots to the measurement and mapping which the initial stage of registration to National Land Agency Office both land registration sporadic and systematic.

Most of the communities consider the process of installing stakes in the framework of determining and determining the boundaries of land parcels in order to comply Principle of Contradictoire Delimitatie is not important because it is not including in the measurement process by the defense officer or the process considered community or applicant as formality in the readiness for measurement, whereas the installation of these stakes is a very important part or as a basis for determining the boundaries of land plot to which the rights are registered. Irawan and Wulansari (2020) in their research on third party measurement in post contradictoire delimitatie principle in Sidoarjo and Pasuruan found out that quality control is needed due to improve the work quality and result of the third party in order to minimize land problems in the future. Moirover, Yuliana et al. (2014) in their study found that there are some problems occurred after the application of contradictoire delimitatie principle, including the land boundary dispute. The registered land has no sign which make the measurement difficult. Therefore it is suggested for the land owner to put a sign on his registered land and monitoring the land measurement process. Therefore, this research aimed to know about the application of contradictoire delimitatie principle in gathering the physical data in Magetan district, Indonesia. Contradictoire delimitatie principle is one of the main key before doing the land measurement. It has function as an evidence and/or agreement between the land owner and people near the registered land.

\section{Methodology}

This research is normative research (doctrine research) which is this research emphasize the law sources, both primary and secondary (Nasution, 2008). The data that used in this research is secondary data, in the form the legislation, law theory, and the opinion of legal experts.

This research used the statute and conceptual approach. The statute approach implemented with the reviewing statutory regulations related with the main of research problem. The conceptual research implemented with examining the views and doctrines that develop in the science of law (Marzuki, 2007).

This research focuses to the literature study, data which becomes the research sources is secondary data including three sources as follows (Ngani, 2012): 
1. Primary law sources are legal materials that have authority (authoritative). The law sources consist of: (a) legislative; (b) official records or minutes of making a statutory regulation; (c) the judge's decision (Ali, 2011).

2. Secondary law sources is the law sources which given the explanation related with the primary law. The secondary law between others, the draft laws, research results, works of legal circles (Soekanto \& Mamudji, 2015).

3. Tertiary law source is the source which given the guide or explanation on the primary and secondary law source, between other such as dictionary, encyclopedia, and other sources which can give the guidance or explanation on the primary and secondary source related with the problem being studied (Soekanto \& Mamudji, 2015).

The data collection implemented with the literature study including the relevant of primary law, secondary law, and tertiary law source with the problems. The literature study implemented through the stages of identification of data source libraries, identification of legal materials needed, and inventory of legal materials (data) needed as well as reviewing, analyzing and processing literature, the legislative, the articles or relating to the problems to be studied.

The third criteria of qualitative research found in this research so it is very reasonable to use qualitative methods in data analysis. This research is comprehensive because of trying to explore the whole. This research is trying to find the harmony relationship found concepts in the primary and secondary law sources with using theory or law doctrine (Podhisita, 2010), related the mechanism for determining the boundaries of land parcels in order to achieve legal certainty.

\section{Results and Discussion}

\section{The implementation of measurement and determination of law plot boundary in Magetan District}

The land registration based on the regulation of Article 19 UUPA aimed to gives the certainty of law and guarantee the legal certainty of land ownership rights for the entire community of Indonesia (Handoko, 2014). The land registration can be implemented systematic or sporadic will produced the certificate as the proof of rights which is valid as strong evidence. Several factors influenced the community interest to register his land sporadically. The sporadic registered implemented based on the request of interested parties, namely parties entitled to the object of registration of the land concerned or their proxies (Sangsun, 2007).

In the process of land registration for the first time mechanism of determination and stipulation of land plot boundary become the important point because to guarantee the legal certainty of the object of his right from the registration of the land. The stipulation of land plot boundary implemented based on the agreement of the bordering rights holders because of the measurements in the field of the bordering parties must be present, so people knows the boundaries of their respective rights and be followed by the installation of boundary markers of the land plot. The applicant and party bordering the land will enter 
into an agreement to determine the boundary of their land in front of local village officials by placing boundary signs (Principle of Contradictoire Delimitatie) in accordance with PMNA/KaBPN No.3 of 1997 Juncto. PP No.24 of 1997.

Realizing the importance of boundary mark placement so if there is no party absence during determination and stipulation of boundary. The owner must authorize someone as his successor with written power, because in the end the parties who have borders will sign the Minutes of Determination of Limits in front of the measuring officer of Magetan Regency National Land Agency Office.

Legal arrangements on the Principle of Contradictoire Delimitatie must applied in the mechanism of determination and stipulation of the land plot in order to achieve legal certainty in land registration for the first time is sufficient to issue it PP No. 24 of 1997 concerning the land registration especially in the Article 18 which refines the improve land registration rules in the PP No. 10 of 1961 in PP No. 24 of 1997 concerning the land registration in the Article 19 paragraph (1). If in the determination of the boundaries of land plot as referred to in Article 18 paragraph (1) holder of the land rights concerned with holders of the rights to the land which have borders. It is endeavored to measure the land plot to be carried out temporarily based on the boundaries which in reality are the boundaries of the land parcels concerned. The Article above is followed up PMNA/ KaBPN No.3 of 1997, which stipulated that the approval and determination of boundaries from the parties is set forth in an official report, namely the Minutes of Research on juridical data and determination of boundaries.

After the boundary mark placement is carried out document and the conditions for land registration activities are completed for the first time, then will implemented the collection and physical data processing implemented the activities of measurement and mapping. The activities of measurement and mapping previously with seeing the registration base map. According to the Head of the Survey, Measurement and Mapping Section of the Office of the National Land Agency of Magetan Regency registration base map is master map (now called Single Map) to know the land plot and function to ease for the measurement officer from the BPN office to know the location of the land and the status of the land.

The Field measurements carried out by the National Land Agency of Magetan Regency implemented terrestrial and using the simple method which is the steps as follows:

\section{The Land Plot Measurement Method}

There are several measurement methods which can be used in the land plot measurement to the land registration activity in Magetan Regency. In this research the National Land Agency of Magetan Regency while implementing the terrestrial measurements with the polar method using the elements of angle and distance, this method is often and most widely used in field measurements. Plot measurements are tied to the main polygon or branch polygon depending on the extent of the plot to the measurement frame. The Distance measurements are carried out manually and optically. Distance manually using a straight steel roll meter with a length of 50 - 60 meters. Meanwhile, optical distance measurement uses theodolite and measuring rod.

\section{The tools for the land plot measurement}

The measurement tools that used in the National Land Agency of Magetan Regency for the land plot measurement as follows:

1) Nikon digital theodolite with the smallest reading angle of 25 ";

2) Angle prism and corner mirror, these tools are only as auxiliary tools. This tool is used to form an angle of 900 ;

3) Yalon, this tool can be used as a tool to mark boundaries. 
Then, the result from the measurement and mapping with the determination of the boundaries of the land parcels will be stated in a Measurement Letter which will then be attached to the Certificate of Land Rights and recorded in the land register book. The result of the boundary stipulation has the legal force if it has been poured and recorded in the land register book so that it can be used for reconstruction in the event of boundary problems in the future. Wahid (2008) explains about the law constructions will build by PP No.24 of 1997 to ensure legal certainty in the issuance of a land title certificate, which includes; the certainty of objects and subjects of rights, certainty of status / rights to land, which can be described as follows:

\section{a. The certainty of object and subject of rights}

The Determination of the exact location of the plot of land is determined the legal certainty value on the value of legal certainty of registered land rights. The object certainty rights including the location and boundaries of the land parcels to which a right is attached. Related with interest served the Land Registration Base Map is indispensable, especially to make sure the location is right a plot of land to which a right has been attached, with the location of the other plot of land, both has been registered or not. This is implemented with purpose in order to implementing the reconstruction to avoid the possibility of a dispute in the future, both related with location, area and boundaries. Moreover, to fulfilling the precautionary principle, so the measurement and land plot stipulation must follow with the agreement by neighbor or commensurate with the boundary of the plot of land (contradictoire dilimitatie). The obstacles that are often faced in implementing the land plot measurement is general difficulty of presenting adjoining land owners or bordering the land object to which the rights will be applied for, especially in the sporadic and systematic land registration (for example in PRONA or PTSL activities), where the applicant and owner which difficulty boundary to presented to implemented measuring the area and only leaving all matters to the village / sub-district apparatus as the executing committee at the village / sub-district level.

Except, it is sometimes the applicant does not know the exact limit correct land parcels, so that the implementation of the signatory veldwerk or plot measurement (GU) images are difficult to obtain definite and frequent data times done inappropriately. And this stuff is already stuff of course, will have an effect on reducing the substance of legal certainty the said object of rights creates uncertainty about the location and boundaries of land parcels and the potential for boundary disputes to arise. Therefore, the installation of boundary marks is an absolute requirement before the measurement of the plot of land is carried out. This is the statute order as mentioned in the Article 17 PP No. 24 of 1997.

Further instructions regarding the form of boundary markers as referred to above shall be further regulated in Article 22 PMNA/Ka.BPN No. 3 of 1997, Meanwhile, for the corner boundaries of land parcels that are clearly located because they are marked by fixed objects such as concrete fences, wall fences or wire fencing poles / stakes, no boundary sign s (vide) in the Article 21 paragraph (2) PMNA/Ka.BPN No. 3 of 1997. The installation of boundary markers and equivalent approval of adjacent land boundaries has a very important role in the process of measuring land parcels to produce plot maps and base maps of land registration with the substance of good legal certainty quality.

The need for a complete land registration map is very important because the map clearly contains technical base points and geographic elements which include the location, shape and boundaries of ownership of each land parcel in an area so as to avoid overlapping the locations of land parcels (Wahid, 2008).

In accordance with the applicable provisions, the original cadastral measurement to obtain a map of land registration is carried out village by village. This was done with the intention that each plot of land had certainty about its exact location, but due to various obstacles the implementation could not yet be carried out as expected. During the validity of PP No. 10 of 1961, village by village measurements were carried out with very limited results, and after the enactment of PP No. 24 of 1997, 
with various limitations, obtaining a basic map of land registration no longer refers to village-by-village measurements, but in sporadic land registration activities (Wahid, 2008).

Sporadic land registration activities are often found in the BPN Office of Magetan Regency because the process can be carried out independently without having to wait for other parties to register the land, so in making a land registration map, measurements are made only of the land plot for which the right is requested does not measure the entire village / sub-district, so that In unifying the map of registration of land rights to one land plot, there is often a mismatch in the image of the object of the right or in other words because the land work map was made at the time the registration of the land plot was made. After the existence of PTSL in 2017, the land work map has started to refer to a single map made at the initial PTSL registration of a certain area, so with this single map it can simplify the process of registering land parcels in that area in the future.

There seems to be no discussion about land issues exhausted, it is in line with the increase in the human population as a legal subject that raises the figure for the need for land and its utilization, but it is inversely proportional to the amount of land availability which tends to be static (Ramadhani, 2012).

The realization of a guarantee of legal certainty for land title certificates also influenced by the certainty of legal subjects as rights holders over land (the subject of rights), because from the study of the certainty of the subject of this right at least will answer about who is entitled. According to Wahid (2008) the certainty of the subject is:

"Certainty regarding who is needed to know who is related to be able to carry out legal actions legally, whether or not there are rights and interests of third parties, and to find out whether or not actions are necessary to ensure control and use of land, concerned effectively and safely."

The certainty of subject has the important role in occupying and shows that has the right or not in control, ownership and utilization of a plot of land. So as to see in detail about certainty of the subject of this right, then the elements that are important to be examined are those related to the identity of the subject, domicile, occupation, citizenship and so on.

In this regard, research on the history of land tenure is also a very important activity and the result is a determining factor in the correctness of the juridical aspects of the issuance of land title certificates. Research on the history of land tenure is required at least to be able to find information about the control process and its transfers, including the parties who controlled the land before the land was controlled by the applicant. In other words, the certainty of the subject of rights is an effort to prove the truth of a right being petitioned for by examining the history of control/ownership of the land coherently from the beginning until it is controlled/owned by the right applicant, including the process of acquiring his rights (either direct control or transfer or transfer of rights). This study is aimed at finding out the applicant's good faith or vice versa and this of course also has an effect on determining the degree of legal certainty of land title certificates.

\section{b. The certainty of status/rights to land}

It is important to study the legal status of land rights to explore the legal certainty of the certificate of land rights that will be issued. There are several legal statuses on each land status containing right and obligation to the party who owns it (Wahid, 2008).

The several land status such as; Customary Freehold Land, Swapraja and Former Swapraja Land and State Land on the land status based on UUPA can give the right, but to give the law certainty guarantee. So the land registered that implemented on the status of the land materially must be in accordance with the land registration procedure as it should be.

Except the land status above, there is still found other some land status which get the special notes in the land registration especially for the land registration first in order to publish the certificate. The special notes are the land use and the user is not contradicting with the National and local regional spatial plans which are regulated based on statutory regulations. 
Event there is several land zones where a right cannot be attached or given the right to a legal subject and is a prohibited area to issue a certificate, namely the land which including inside protected areas. Such as the land including the protected areas for example, land that enters the border of rivers, roads, seas and so on.

In the issuance of certificate of land rights must in accordance with the previous inherent land status, it means that if the right of certificate publishes above the status of substance land, so it cannot inherent by the right according to law. Thus, from the legal aspect, the public certificate means said as a state administrative decision that is materially flawed. This means certificate containing the legal flaws on the certificate, it is not guaranteed of the legal certainty.

The land registration law or the registration of rights on the land is the important event because it is related with concerning the aspect of civil rights of a person is not just administrative activity (Ismaya, 2013).

\section{Legal consequences if the implementation of measurements and boundaries of land parcels in Magetan Regency is not in accordance with the principles of safe land registration.}

Based on the interview with the Head of BPN Measurement and Mapping Subsection, Magetan Regency consequence law if the measurement and mapping in the land plot boundary is not accordance with the field fact in the Magetan Regency, especially to the land plot measurement to the identification method as follows:

1. The land plot in the certain plots is not seem certainty in the Registration Base Map in the form of Photo Map;

2. Not ideal registration base maps and engineering base points in the national coordinate system on the land plot measurement and;

3. Not accurate in the field data and letter.

There is not accurate data in the field with the letter which caused by the registration map during using as the first filter in the analysis activity when a plot of land requested to published in the first certificate is not fulfils the standard as base map (which is now a single map of land registration). One of the function of land registration map is to avoid the double certificate publishes. If a land plot will published is mapping in the mapping registration and it turns out that at that location there is already a drawing of the field whose certificate has been issued, so the land plot is unable to publish the certificate. Moreover, if a plot of land to be issued is mapped on the Registration Map and only in the location is empty and there is not land plot picture so there is two possibilities which can be concluded as follows: 1) the certificate has not been issued in the field; 2) the land plot has not yet issued the certificate but no yet mapped in the registration map.

The legal consequences if the land boundary measurement is not accordance with the data in the field and in the land book may result in uncertainty about the object of the right which is written in the certificate that has been issued by BPN, so that in the future it can cause boundary problems, both boundary disputes and double certificates. From this research can be taken the examples in the problem boundary can causes the legal act as exchange of objects of land rights and cancellation of certificates due to multiple certificates appearing from the same object of the right.

For the exchange process in Widorokandang-Magetan Village, according to information from the Head of the section for land determination and registration of BPN Magetan Regency, it was caused by a human error at the time of Prona implementation in 2010, namely in the process of placing a measuring letter so that BPN suggested maintaining land data through the process. Exchange because the NIB, the land area, the boundaries of the land parcels and the shape of the land image are in accordance with a single land registration map. So there is no need for the creation of a new measurement letter and drawing (can be reconstructed from the previous boundary determination). 
For the exchange process is "A legal act in the form of transferring title to the land concerned to the party who exchanges it." (Perangin, 1994) Exchanging land rights as a legal act of transferring land rights based on customary law also has cash, clear and real characteristics. Exchanging land rights based on customary law is currently undergoing modernization and adjustment without changing its essence as a legal act of transferring land rights which is cash, clear and real (Harsono, 2010). This can be seen from the regulation in the Article 37 Paragraph (1) PP No. 24 of 1997(PP 24 Tahun1997, Pasal 37 Ayat (1), 1997). Modernization and adjustments to the cash, clear and real nature can be seen from the presence of a Land Deed Making Officer (hereinafter referred to as PPAT) to assist the Head of the Land Office in carrying out land registration, which is with making the deed which become the proof which has been implemented and the legal act of transferring land rights by the parties(PP 24 Tahun1997, Ps. 1 Angka (24), 1997).

The function of PPAT Deed (Deed of Exchange) in the exchange of the land ownership rights as follows:

1. As a proof of a tools

PPAT Deed (Deed of Exchange) proves that it is true that the parties have exchanged land rights by the parties. Except, because exchange of land rights implemented is the legal act of transferring land rights, PPAT Deed (Deed of Exchange) also proof has the transfer of land ownership rights from the first party to the second party and vice versa. But PPAT Deed (Deed of Exchange) which made to tied and heirs, this causes the PPAT administration is closed for public (Harsono, 2010).

2. As the condition for registering the transfer of land rights due to exchange at the Land Office

The Registration of transfer of land rights due to exchange in the BPN office aimed to the party gets the legal certainty for the exchange of land rights that have been carried out. The legal certain realized with the issuance of a strong means of proof, namely a certificate of land rights by BPN Office. The land registration administration in the Office of BPN has the openness for public (principle of publicity/openbaarheid). Moreover, with notes of transfer of land rights because exchange to the land book and certificate on the concerned land right, but the third party is also deemed to know that the parties are the holders of the new land rights (Harsono, 2010).

Before the party implement land rights exchange, the first the parties agree to enter into an agreement or agreement to make the exchange (which land rights will be exchanged and how the exchange is carried out). The agreement can be called as the agreement of implementing exchange (Perangin, 1994). The agreement will exchange based on nature and legal consequences can be called as Obligatoir agreement, which means that the agreement to exchange the exchange has not resulted in the transfer of land ownership rights, in the agreement; there is a promise to exchange ownership rights to land. To switch the land right made by PPAT. The land right exchange based on the nature and the legal can be called as material agreement (Budiono, 2010). Therefore, the validity of an exchange of land rights is determined by the fulfillment of 2 (two) things as follows:

1. Fulfillment of the legal conditions of an agreement on the exchange according to legal agreement; (Pasal 1320 KUH Perdata, n.d.)

2. Fulfillment of legal conditions of legal acts of right exchange according to the National Land Rights. 
For the process of double certificate in the sub-district of Sarangan according to the Head of section for controlling and handling disputes at BPN Magetan Regency based on the juridical data on one of the multiple certificates is defective in administrative law in its issuance until the certificate must delay.

In implementing the certificate cancellation, first it must implement the cancellation of title to land that he owns and to determining the land right cancellation in the first must know the acquisition of land rights, there are 2 kinds of the acquisition of land rights namely originair and derivatives, so it will causes some ways/procedure of cancellation. First, if the right obtained in originair, there is a high probability that there is an error in the determination due to defects in the evidence of acquisition, error in determination, so it will causes loss to the other party according to the general principle of granting rights is the rightful. The mechanism of the demand of right cancellation is not yet regulated in details and complete in several constitutions(PMNA/KaBPN No.9 Tahun 1999, 1999) but it is in accordance with the policy in the practice application can be filed through BPN Office to obtained the decision if gives the land rights caused by the law/administration flaws in the issues as it found by BPN Office.

The certificate cancellation caused by the right ownership which not fulfils the stipulated regulation in the decree granting his rights, or the error / mistake in granting their rights. The mistakes happens in many things causes from the administration sight, including the application of regulation or the reason which filed as the reason for the application for his right is in a state that does not have legal force, then know or without from the results of the court's decision. If the grant of land right/ownership right is cancelled, so the loss is borne by the right recipient.

In accordance with the regulation in the Article 105 PMNA/Head of BPN No. 9 of 1999 the cancellation on the land right implemented with the decision of Head of the National Land Agency or bestow to the Regional Office or the appointed official. So, in the principle of land right the cancellation decision letter which authorizes the issuance in accordance with the delegation of authority which stipulated in PMNA/Head of BPN No. 9 of 1999.

As it written in the Article II, Article IV, and Article VII the converting regulation of UUPA, The land registration can be carried out based on the fact that the physical control over the land parcel concerned for 20 consecutive years by the land registration applicant and his predecessors, provided that:

1. Control and use of the land concerned implemented in real and good intention during 20 years or consecutive.

2. The fact of control and use of land as long as it is not inviolable and area is considered recognized and justified by the customary law community or the village / the village concerned.

3. It can be strengthen with the witnesses of trusted people.

4. It gives the chance to the other party to file an objection through the announcement as referred to.

Stelsel publication that used in UUPA is Negative stelsel contains the positive element because producing letter of proof of rights which is valid as a strong means of proof, based on the Article 19 Paragraph (2) point c, Article 32 Paragraph (2) and Article 38 UUPA. The word "strong" means not absolute, so bring the consequence that everything listed inside have the legal strength and accepted as the correct information with there is no other party which proofed and vice versa with the proofed tools that the certificate is not true.

The formulation with the cancellation of land right found in the Article 1 Paragraph 14 PMNA/KaBPN No. 9 of 1999 which is cancellation of a decision regarding the granting of a land right because the decision contains legal flaws in its issuance or implements a court decision that has permanent legal force. Evidence regarding a certificate of land title that contains legal / administrative defects must be carried out through a court process at the District Court. This evidentiary 
process basically starts from the existence of a lawsuit from the plaintiff who feels that his rights have been harmed by the defendant, until the end of the proceedings, namely the implementation of the verdict or execution. But if the dispute can be resolved amicably between the disputing parties, the settlement is sufficient within the scope of the local Regency / City BPN Office.

According to the explanation above it can be concluded that the legal consequences of the mechanism for determining and determining the boundaries of land parcels in the measurement process do not apply the principle of safety so that land rights holders do not have legal certainty from the certificate held over the object of their rights and can lead to other legal actions from registration of the land. So it is hoped that the Head of the Magetan Regency BPN will always carry out evaluations and directions to the entire team of land registration officers so that in carrying out their duties more carefully and carefully so that the legal products produced can be accounted for which is in accordance with PP No. 24 of 1997 Juncto. PMNA/KaBPN No.3 of 1997.

\section{Conclusion and Suggestions}

\section{Conclusion}

1. In the Magetan Regency National Land Agency Office in determining and stipulated the land plot boundary based on the PP No. 24 of 1997 and PMNA/KaBPN No.3 of 1997 which is determine the determine the location of the plot of land, put up boundary signs then measured and mapped. The result from the determination of land parcel boundaries in Magetan Regency has been in accordance with the principle of safe land registration. If there are problems related to land parcel boundaries, for example, lost boundaries or shifted boundaries, it can be reconstructed in accordance with the land boundaries that have been previously determined.

2. Law consequences if the land boundary measurement is not accordance with the field fact causes the absence of legal certainty over land title certificates. There was an exchange of boundaries in Widorokandang Village due to an error in the placement of the Measurement Letter by the juridical data collection and research team. Moreover, in the issuance of a certificate there is no guarantee of legal certainty for the land owner because the object of his right is not in accordance with the reality in the field. There was an overlap in Sarangan Village due to the absence of a single land registration map which made mistakes in determining land boundaries and making land registration base maps which resulted in administrative defects in the issuance of the certificate. So that 4 (four) certificates were issued in the same 1 (one) plot of land.

\section{Suggestion}

In implementing the land plot boundary, Magetan Regency Land Office should always refer to the provisions PP No. 24 of 1997 and PMNA/KaBPN No. 3 of 1997 with the regulations relating to the determination of the boundaries of land parcels in the future so as to fulfill the principle of safe land registration. Magetan Regency National Land Agency Office should always implementing evaluation periodically on the team for implementing land registration and supervising the performance of the team for implementing land registration should be more thoroughly and carefully so the result is more accuracy and legal product which legal products that are issued have more guaranteed legal certainty.

\section{References}

Ali, Z. (2011). Metode Penelitian Hukum (3rd ed.). Sinar Grafika.

Budiono, H. (2010). Ajaran Umum Hukum Perjanjian dan Penerapannya di Bidang Kenotariatan. PT. Citra Aditya Bakti. 
Research, Society and Development, v. 10, n. 6, e59710616477, 2021

(CC BY 4.0) | ISSN 2525-3409 | DOI: http://dx.doi.org/10.33448/rsd-v10i6.16477

Handoko, W. (2014). Kebijakan Hukum Pertanahan. Thafa Media.

Harsono, B. (2010). Hukum Agraria Indonesia, Sejarah Pembentukan Undang-Undang Pokok Agraria, Isi Dan Pelaksanaannya (Jilid I). Djambatan Publisher.

Irawan, D. S., \& Wulansari, H. (2020). Pengukuran Pihak Ketiga Pasca Asas Contradictoire Delimitatie di Kabupaten Sidoarjo dan Pasuruan. Jurnal Tunas Agraria, 3(2)

Ismaya, S. (2013). Hukum Administrasi Pertanahan. Graha Ilmu.

Marzuki, P. M. (2007). Penelitian Hukum (Cetakan II). Kencana Prenada Media Group.

Nasution, B. J. (2008). Metode Penelitian Ilmu Hukum. Mandar Maju.

Ngani, N. (2012). Metodologi Penelitian dan Penulisan Hukum. Pustaka Yustisia.

Pasal 1320 KUH Perdata, Pub. L. No. Pasal 1320.

Perangin, E. (1994). Hukum Agraria Di Indonesia Suatu Telaah Dari Sudut Pandang Praktisi Hukum. Rajawali Pers.

PMNA/KaBPN No.9 Tahun 1999, (1999).

Podhisita, C. (2010). Theoritical Terminological, and Philosophical Issues in Qualitative Research, Qualitative Research Methods.

PP 24 Tahun1997, Pasal 37 Ayat (1), (1997).

PP 24 Tahun1997, Ps. 1 Angka (24), (1997).

Ramadhani, R. (2012). Benang Merah: Alas Hak dengan Sengketa Pertanahan. Harian Rakyat Bengkulu.

Sangsun, F. S. (2007). Tata Cara Mengurus Sertipikat Tanah. Visimedia.

Soekanto, S., \& Mamudji, S. (2015). Penelitian Hukum Normatif: Suatu Tinjauan Singkat. Rajawali Pers.

Wahid, M. (2008). Memaknai Kepastian Hukum Hak Milik Atas Tanah; Suatu Analisis dengan Pendekatan Terpadu Secara Normatif dan Sosilogis. Penerbit Republika.

Yuliana, R., Zulaekha, S., \& Suryani, S. (2014). Penerapan Asas Contradictoire Delmitatie dalam Penetapan Batas pada Proses Pendaftaran Tanah dan Permasalahannya di Kabupaten Malang. Universitas Pekalongan. 